\title{
Curriculum Management in the Intercultural School
}

\section{Andhyarnita Pratami ${ }^{*}$, Sugiarto², Masduki Ahmad ${ }^{3}$}

1,2,3 Universitas Negeri Jakarta, DKI Jakarta, Indonesia

\author{
A R T I C LE I N F O \\ Article history: \\ 20 January 2020 \\ Received in revised form \\ 23January 2021 \\ Accepted 2 February \\ 2021 \\ Available online 25 \\ February 2021

Kata Kunci:
Manajemen, Kurikulum,
Evaluasi
Keywords:
Management, Curriculum,
Evaluation

\begin{abstract}
A B S T R A K
Manajemen kurikulum merupakan salah satu komponen penting dalam proses penyelenggaraan pendidikan di sebuah satuan pendidikan. Oleh sebab itu, manajemen kurikulum hendaknya mendapat perhatian lebih sebagai upaya untuk mengoptimalkan kualitas penyelenggaraan pendidikan. Penelitian ini bertujuan untuk menganalisis manajemen kurikulum di sekolah intercultural. Fokus penelitian ini adalah komponen manajemen kurikulum yang terdiri dari tahap perencanaan kurikulum, tahap pengorganisasian, tahap implementasi, dan tahap evaluasi. Penelitian ini merupakan penelitian dengan menggunakan pendekatan deskriptif kualitatif. Data dalam penelitian ini dikumpulkan melalui observasi dan wawancara dengan kepala sekolah, guru-guru, dan perwakilan pengembang kurikulum. Data yang telah dikumpulkan kemudian dianalisis dengan menggunakan metode analisis data menurut Milles dan Huberman yang terdiri dari reduksi data, presentasi data, dan pengambilan kesimpulan. Hasil penelitian menunjukkan bahwa manajemen/pengelolaan kurikulum pada sekolah intercultural sudah dilaksanakan dengan mengikuti tahap-tahap pengembangan kurikulum yang meliputi tahap perencanaan, pengorganisasian/koordinasi, implementasi, dan evaluasi kurikulum.
\end{abstract} Pelaksanaan tahap-tahap pengembangan kurikulum tersebut menunjukkan bahwa proses manajemen kurikulum sudah terlaksana dengan kategori baik.

\begin{abstract}
A B S T R A C T
Curriculum management is one of the important components in the process of providing education in an educational unit. Therefore, curriculum management should receive more attention as an effort to optimize the quality of education. This study aims to analyze curriculum management in intercultural schools. The focus of this research is the component of curriculum management which consists of the curriculum planning stage, the organizing stage, the implementation stage, and the evaluation stage. This research is research using a qualitative descriptive approach. The data in this study were collected through observation and interviews with principals, teachers, and representatives of curriculum developers. The data that has been collected is then analyzed using the data analysis method according to Milles and Huberman which consists of data reduction, data presentation, and conclusion drawing. The results of the study indicate that curriculum management/management in intercultural schools has been implemented by following the stages of curriculum development which include planning, organizing/coordinating, implementing, and evaluating curriculum stages. The implementation of the stages of curriculum development shows that the curriculum management process has been carried out in a good category.
\end{abstract}

\section{Introduction}

The era of the industrial revolution 4.0, technological advances have changed the face of Indonesian education (Aziz Hussin, 2018; Yamin \& Karmila, 2019). Education to produce students who are following the needs of the world of work, the economic system, and the interaction patterns of everyday human life (Idhamani, 2020; Pangondian et al., 2019). Therefore, to create an education system that is relevant to technological advances, it is necessary to have a curriculum system that includes the needs of industry and economic actors in the future (Verawadina et al., 2019). what underlies the creation of the 2013 curriculum, which uses the 21st-century learning framework, namely a curriculum that emphasizes the ability to think critically, solve problems, understand information and communication technology, and strengthen character and spiritual education (Fernandes, 2019). The 2013 curriculum is a curriculum that focuses on a scientific approach, authentic and thematic integrative assessment in learning (Bahtiar, 2019; Haryanti et al., 2021). The 2013 curriculum with a philosophical foundation provides the basis for developing all potential students to become quality Indonesians listed in the national education goals (Safitri \& Oktaviana, 2017). The 2013 curriculum produces a critical and creative

Copyright (C) Universitas Pendidikan Ganesha. All rights reserved. 
generation of Indonesia following the times' demands (Budiani et al., 2017). Although the implementation of the 2013 Curriculum has only been running, several educational institutions combine the 2013 curriculum with the Cambridge curriculum. It is possible because, according to research conducted by Shafa in his journal entitled "Characteristics of the 2013 Curriculum Learning Process", the characteristics of the 2013 curriculum are the same as the Cambridge curriculum (Maudina \& Hasanah, 2020). Although the two curricula have similarities, the main objective of educational institutions to use a combination of the two curricula is to improve students' quality to be able to compete internationally and enter top universities both domestically and abroad (Rahmadoni, 2018).

Likewise, what happened at SD Mentari Bintaro. The school applies the 2013 National Curriculum alongside the Cambridge Curriculum. The purpose of implementing the 2013 Curriculum alongside the Cambridge Curriculum is to create innovation and prepare advanced and global generations to improve the quality of schools. Bintaro Mentari Intercultural School (MIS) Elementary School is one of the favorite private schools located in Bintaro, South Tangerang. SD MIS Bintaro has 30 study groups with 93 teachers and 12 administrative staff with an average of 5 classes at each level. Bintaro Mentari Elementary School began using the Cambridge curriculum in 2011 and began side by side with the 2013 curriculum since the 2014/2015 school year. This school uses the language of instruction of English with the Cambridge curriculum and the 2013 curriculum. SD Mentari is a multi-language school; its students learn Indonesian, English, and Mandarin since they are still in Kindergarten (TK). In the education system, the curriculum is one component that has a strategic role. The curriculum cannot stand and run alone but must plan, implemented, controlled, and evaluated. The importance of curriculum management is that curriculum management includes planning, implementing, and evaluating curriculum activities to produce quality output. Under the educational goals, curriculum management dramatically affects the success of schools' learning process. If the curriculum management does not go well, the school's teaching and learning process will experience obstacles so that the goals to be achieved through the teaching and learning process are also constrained (Bailey et al., 2002; Machin, 2014). On the other hand, if curriculum management is organizing well, the school's conditions will be conducive to developing a quality learning process (Suryana, 2019; Viciana \& Mayorga-Vega, 2016).

In general, in Indonesia, curriculum management must be developed according to the 2013 Curriculum (Kurniasih \& Sani, 2014; Winangun, 2020). Therefore, the autonomy given to schools in managing the curriculum does not only prioritize the needs and achievement of school targets but also carry out national policies (Lazwardi, 2017; Purwadhi, 2019). For this reason, in order to achieve educational goals, structured planning is needed. Teaching and learning can be made more meaningful by understanding the aims of education. It should then understand as the basis of an educational taxonomy, in which appropriate teaching and learning practices can identify the domain of educational objectives (Kurangi et al., 2017; Varfolomeyev et al., 2015). Appropriate educational goals will assist the curriculum management process-the research background needs for curriculum management at the Mentari Intercultural School Bintaro Elementary School, South Tangerang. Mentari Elementary School can apply the 2013 Curriculum alongside the Cambridge Curriculum to create innovation and prepare advanced and global generations as part of efforts to improve school quality. This study aims to investigate the curriculum management of the Mentari Intercultural School Bintaro elementary school. Therefore, this research's focus is Curriculum Management at the Mentari Intercultural School Bintaro Elementary School, which starts from the planning, organizing, implementing, and evaluating stages of the curriculum.

\section{Method}

This type of research is a descriptive study using a qualitative approach. This type of descriptive research is to describe a phenomenon and its characteristics (Aulia, 2020). Through a descriptive qualitative approach, this research can describe the constraints contained in research related to curriculum development management at the Mentari Intercultural School Bintaro Elementary School systematically and following the facts in the field. There are two data sources in this study; the first is primary data, where the data source comes from interviews conducted on respondents or research subjects referred to as informants. While the second is called secondary data, which is data in the form of documentation related to curriculum development management at Mentari Bintaro Elementary School, South Tangerang City. This research's data collection techniques are observation and in-depth interviews with key informants and equipped with documentation techniques. The data analysis technique used in this research uses the "descriptive evaluative" technique, an analysis technique by describing the data that has a process and discussed and evaluating it sharply and in detail to produce a conclusion on the processed data. According to Milles and Huberman, this technique is defining analysis as consisting of 
drawing verification. In other words, data analysis and diversification are interrelated and co-occur, with the stages of data reduction, data presentation, and concluding (Sugiyono, 2015).

\section{Result and Discussion}

\section{Results}

Mentari Intercultural School Bintaro (MISB) Elementary School was founded in June 2004 and is a Collaborative Education Unit School (SPK) managed by the Indonesian Child Development Foundation. This school has the following vision; Morally upright, engaging communicators, never too busy to lend a helping hand, Tech-savvy (Technology), Able leaders, Responsible citizens (Responsible), Innovators, and problem solvers (Innovating and Problem Solvers). The parties appointed as research informants consisted of representatives of SD Mentari Intercultural School Bintaro, such as the principal, teacher representatives, and representatives of the curriculum section. The informants' determination was based on the informants' knowledge and involvement in the curriculum at SD Mentari Intercultural School Bintaro.

\section{Curriculum Planning}

Curriculum planning is a process that involves collecting, sorting, and selecting relevant information from various sources. This information to design a curriculum in teaching and learning activities allows students to achieve learning goals. Curriculum planning must also contain educational goals and clarify with concrete illustrations to develop a more specific curriculum plan. Curriculum planning at SD Mentari Intercultural School Bintaro begins with formulating a unit-level curriculum. In this formulation, the school's things are making preparations since April before the start of the new school year. The preparatory stage begins with evaluating the previous year's program. The evaluated parts include the module and schedule of the lesson plan (lesson plan), learning outcomes, programs, and the educational calendar. The school education calendar refers to the Education Office's education calendar by taking into account the needs of schools related to schools' policies. SD Mentari Intercultural School Bintaro divides one academic year into four terms. At the end of each term, SD Mentari will conduct an Assessment as an evaluation for students, followed by a Term Break. SD Mentari Bintaro conducts an assessment using the Minimum Completion Criteria (KKM) system as the minimum threshold for achieving completeness or graduation. The determination of the KKM at SD Mentari Bintaro follows the national KKM standard, namely 65. However, based on the discussion results by the teaching team at schools, some subjects have KKM 70. The following is the table of KKM in SD Mentari Bintaro.

Table 1. Minimum completeness criteria (KKM) SD Mentari Intercultural School Bintaro

\begin{tabular}{clccccccc}
\hline \multirow{2}{*}{ No } & \multicolumn{1}{c}{ COMPONENT } & \multicolumn{5}{c}{ Minimum Completeness Criteria } & \multirow{2}{*}{ (KKM) } \\
\cline { 3 - 6 } & & I & II & III & IV & V & VI & \\
\hline A. & Subject & & & & & & & \\
1. & Pendidikan Agama & 70 & 70 & 70 & 70 & 70 & 65 & \\
2. & Pendidikan Kewarganegaraan & 70 & 70 & 70 & 70 & 70 & 65 & \\
3. & Bahasa Indonesia & 65 & 65 & 65 & 65 & 65 & 65 & \\
4. & Matematika & 65 & 65 & 65 & 65 & 65 & 65 & \\
5. & Ilmu Pengetahuan Alam (science) & 65 & 65 & 65 & 65 & 65 & 65 & \\
6. & Ilmu Pengetahuan Sosial (social studies) & 65 & 65 & 65 & 65 & 65 & 65 & \\
7. & Seni Budaya dan Keterampilan & 70 & 70 & 70 & 70 & 70 & 65 & \\
8. & Bahasa Inggris & 65 & 65 & 65 & 65 & 65 & 60 & \\
9. & Komputer & 70 & 70 & 70 & 70 & 70 & 65 & \\
10. & Bahasa Mandarin & 65 & 65 & 65 & 65 & 65 & 65 & \\
11. & Pendidikan Jasmani, Olahraga dan Kesehatan & 70 & 70 & 70 & 70 & 70 & 65 & \\
\hline
\end{tabular}

At the time of the Covid-19 pandemic, the strategies or methods of delivering lessons were different. If the 2019/2020 school year teaching and learning activities can face-to-face, then in the 2020/2021 academic year, the method of learning is distance or online. Mentari Intercultural School Bintaro Elementary School educators ensure the platform and resources used are available to all students to support distance learning. Teaching and learning activities using Zoom and various media such as presentations and videos that use internet networks such as YouTube. Learning materials can also be accessed using the Kahoot and Edmodo applications. The assessment process by on the activeness of 
students, submission of assignments, and the final exam. Where the weight of the assessment divides into $70 \%$ assessment of daily student activities, $15 \%$ for the mid-exam, and 15\% for the final exam, SD Mentari Bintaro does not use a ranking system; the school gives appreciation to children who excel and are the best in their class. During the pandemic, school appreciation focuses more on children's character. Children will get appreciation if they are always present on time during Zoom sessions.

\section{Organizing the Curriculum}

Organizing the curriculum is a pattern or design of curriculum materials whose purpose is to facilitate students in carrying out learning activities to achieve learning objectives effectively. Organizing the curriculum requires a clear curriculum structure. The curriculum structure describes the conceptualization of curriculum content in subjects, content/subjects in the curriculum, distribution of content/subjects in semesters or years, learning load for subjects, and learning load per week for each student. The curriculum structure is also an application of organizing the curriculum in the learning system and organizing the learning load in the learning system. Organizing the curriculum between the national curriculum and the Cambridge curriculum at SD Mentari Intercultural School Bintaro is made as a whole or integrated and complementary. SD Mentari Bintaro integrates the two curricula to create their school curriculum based on each subject. There are three integrated subjects, namely English, Maths and Science. To harmonize and socialize the Cambridge curriculum and the National Curriculum, the school holds Professional Development (PD) Training for its educators at the beginning of each new school year. SD Mentari Bintaro has 36 educators, with a percentage of $68 \%$ of educators who are Indonesian citizens and $32 \%$ of educators who are foreigners. All educators have skills in using applications in online learning.

Following organizational structure (Figure 1) in incoordination, several educators were select as class coordinators. This selection per on educators' experience and tenure at SD Mentari Bintaro, hoping that they can share their experiences with other educators with the experience and a more extended work period. The coordinator has the responsibility to prepare the program annually and supervise each class's teaching and learning process at each level. The coordinator has a particular task to supervise teachers' readiness regularly by conducting observations in each term, holding workshops, preparing lesson plans, preparing budget plans, compiling online subject schedules, and preparing annual programs (events) regarding the implementation of learning, coordination between the principal and the coordinators by through the WhatsApp group. The principal also holds regular meetings twice a month. The meeting is to discuss developments or the latest information related to the teaching and learning process. The principal's meetings with the coordinator and with the school foundation are carried out regularly and scheduled every month.

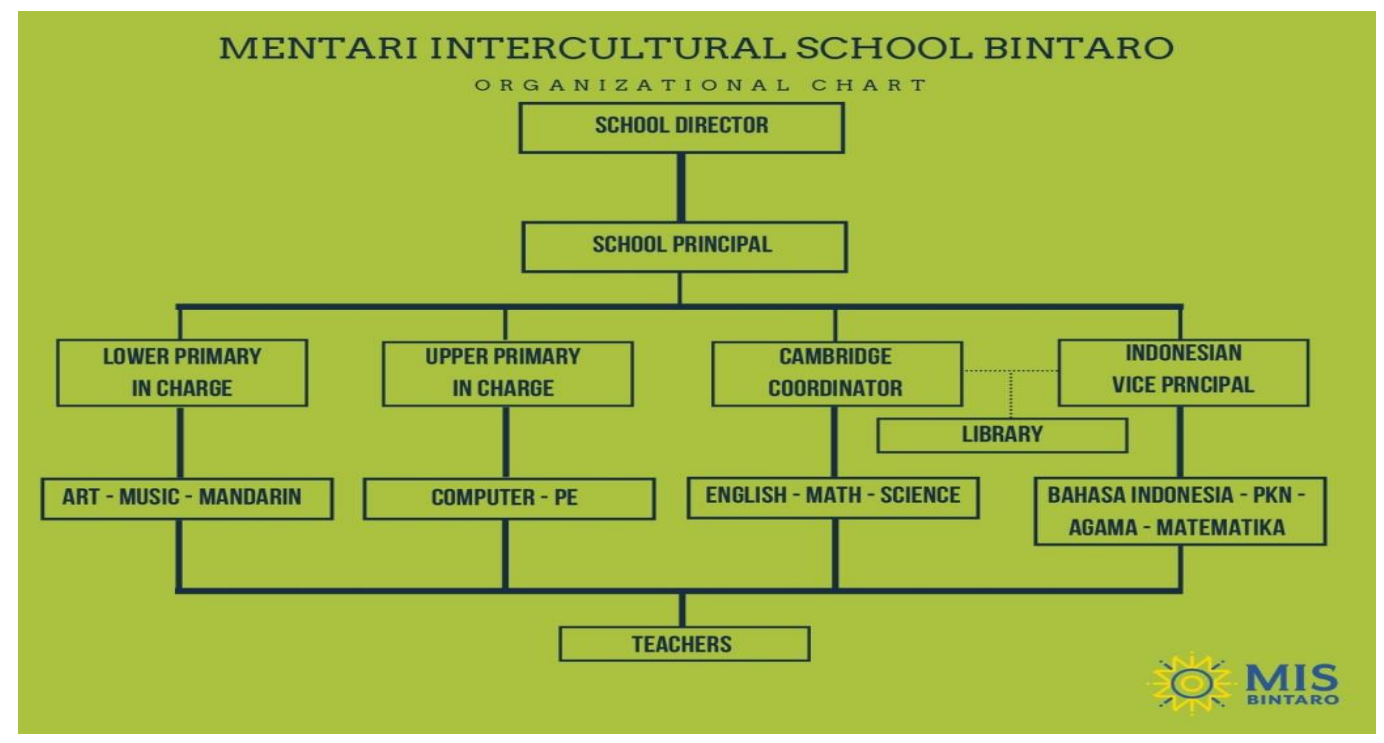

Figure 1. Organizational Structure of SD Mentari Intercultural School Bintaro

\section{Implementation of the Curriculum}

The learning process at SD Mentari Intercultural School Bintaro during the pandemic was carried out online through Zoom. The difference in the learning process is only in terms of strategies or methods and learning models. If previously the face-to-face learning model, now the online learning model. Because 
at the time of the pandemic, learning under online and several learning processes could use more than one media. Of course, it required a different strategy. Therefore, teachers are required to be more creative in conveying learning to children. So, the interaction between the teacher and the child cannot be one-way; the children listen and carry out discussions and presentations with one another. The media used can be books, pictures, videos, presentations, and online whiteboards. SD Mentari Bintaro sends Home-Based Learning (HBL) packages every two weeks, and the children then collect part of their assignments every two weeks. As for learning at home, schools maximize the use of technology and applications such as Zoom and Edmodo applications to conduct tests or evaluations. Not all learning is done online through Zoom; some lessons also require students to do assignments offline, which are then collected to their respective teachers once every two weeks. Because SD Mentari Bintaro still wants to present a learning atmosphere almost the same as in school. With this strategy, each student can maintain their learning motivation by not being constantly in front of gadgets.

SD Mentari Bintaro uses the Cambridge Primary curriculum, especially for the basic education level. The Cambridge curriculum aims to develop each child's potential so that students can be confident, responsible, and innovative. The Cambridge curriculum provides guidelines for curriculum development and a variety of learning methods in the classroom. The subjects integrated between the Cambridge curriculum and the national curriculum are English, Math, and Science. In terms of assessment, the Cambridge Primary Checkpoint Test will require assessment by educators at SD Mentari Intercultural School Bintaro and sent directly to Cambridge for a final assessment and graduation certificate. The Cambridge Primary Checkpoint Test aims to help educators at SD Mentari Bintaro monitor each child's performance and structure future learning. During the curriculum implementation at SD Mentari Intercultural School Bintaro, each periodic supervision and monitoring done. Supervision and monitoring are carried out in stages, aiming to check teachers' readiness in each class at the beginning of the school year and to conduct regular observations every month in each class. The next level is the principal. Supervision and monitoring carried out by the principal are carried out at certain times. The school supervisor then carries out supervision and monitoring. The supervisor of SD Mentari Intercultural School Bintaro is an officer assigned by the education office in South Tangerang. School supervisors carry out regular and scheduled supervision and monitoring of the school principal. If there is a visit from a supervisor, then some teachers are obliged to come to school.

\section{Curriculum Evaluation}

Curriculum evaluation is a systematic study of the benefits, appropriateness of the applied curriculum's effectiveness, and efficiency. In other words, curriculum evaluation is applying scientific procedures to collect valid and reliable data to make decisions about the ongoing or implemented curriculum. Curriculum evaluation can be input for necessary improvements in the curriculum to improve the curriculum every year. SD Mentari Intercultural School Bintaro holds curriculum evaluation activities every April and May. This evaluation also considers the results of the supervision and monitoring carried out during the school year. The school also considers the input and direction of the official submitted through the school supervisor. Especially in the implementation of the two curricula, the curriculum components that content and material of the SD Mentari Bintaro curriculum and will also look at the results students have achieved. The Cambridge curriculum management at SD Mentari Bintaro in the 2020-2021 academic year has experienced an adaptation to the ongoing pandemic conditions. The adapted things are the formulation of learning objectives, the form of learning, and student learning outcomes. The formulation of learning objectives is more emphasized on student learning experiences and not on learning targets. The form of learning is distance learning online / offline and so that students' grades meet the KKM set by the school.

\section{Discussion}

The scope of curriculum management includes planning, organizing, implementing, and evaluating the curriculum. At the unit level of education, the curriculum prioritizes the realization and relevance of the national curriculum with each region's needs and the conditions of the school concerned so that the curriculum is a curriculum that has integrity both with students and the environment in which the school. The Cambridge curriculum selection as the curriculum used at SD Mentari Bintaro has been made by considering regional needs and school conditions. The area around SD Mentari Bintaro was modern families with high expectations for implementing education in schools. The school chose the Cambridge curriculum because it felt able to meet these expectations and was well-known to students' parents. Therefore, the implementation of education at SD Mentari can be of great interest to parents of students in the school area. The planning stage of the curriculum at SD Mentari Intercultural School Bintaro starts with internal coordination to evaluate the curriculum in the previous academic year. The 
research results concluded that SD Mentari continued to use the Cambridge curriculum combined with the national curriculum because the Cambridge curriculum is flexible and can adapt to each country's existing national curriculum. The price is quite affordable for residents. Bintaro. This stage is good enough because SD Mentari Bintaro carries out systematic curriculum planning. SD Mentari Bintaro conducts curriculum planning every year by considering the output of the curriculum in the previous school year. This curriculum planning also has clear educational goals and learning targets.

Organizing the curriculum at SD Mentari Intercultural School Bintaro requires a clear curriculum structure. The curriculum structure describes the conceptualization of curriculum content in subjects, the distribution of subjects in one year, the learning load for subjects, and the learning load per week for each student. From the research results, it was concluded that the organization of the curriculum at SD Mentari Intercultural School Bintaro was made unified or blended; some of the subjects in the curriculum structure were made unified and integrated between the Cambridge curriculum and the National curriculum. In contrast, several other subjects still followed the applicable National curriculum in Indonesia. This stage is good enough because each integrated subject is selected based on student needs and school characteristics. The national curriculum has a different approach to the Cambridge curriculum. The Cambridge curriculum is flexible so that the content and materials can be adapted to the national curriculum. Then causes the two curricula to blend harmoniously. Besides, SD Mentari Intercultural School Bintaro also holds training every year to socialize the Cambridge curriculum and the National Curriculum, held at the beginning of each new school year. Several teachers are coordinators who will coordinate and plan in each area and subject contained in the two curricula. Then it was socialized to all teachers who teach at SD Mentari Intercultural School Bintaro.

At the stage of implementing the curriculum at SD Mentari Intercultural School Bintaro, the curriculum formulates goals that must be achieved and understand the learning experience that each student must-have. From the results of this study, the implementation of the SD Mentari curriculum in the 2020-2021 school year had a slight difference from implementing the curriculum in the previous academic year. This stage is not maximal enough because the implementation of the curriculum implementation has not been so effective as implementing the curriculum in the previous academic year. Students have not achieved several learning targets at SD Mentari Bintaro. This school year, all students must carry out teaching and learning activities at home. Of course, creates challenges, both for teachers, students, and also their parents. Therefore, the school will always collaborate between teachers at school and parents at home. When these challenges can be adequately overcome, in the future, of course, it will make curriculum management at SD Mentari Intercultural School Bintaro management that is adaptable and can be applied in various conditions. The curriculum evaluation phase at SD Mentari Intercultural School Bintaro starts from a curriculum evaluation activity every April. This evaluation also considers the supervision and monitoring results carried out by educators during the school year. In the 2020/2021 academic year, the Cambridge curriculum's implementation underwent significant changes, namely by implementing distance learning. From the results of this evaluation, the Cambridge curriculum management at SD Mentari Bintaro in the 2020-2021 academic year can adapt to pandemic conditions. Therefore, it can be concluded that the distance learning process to date can be said to be effective by the school because the school has successfully implemented its curriculum. This stage is good enough because the students already have the awareness to study independently in their own homes. Students have begun to learn using technology, and student values have met the KKM determined by the school.

In the education system, the curriculum is one component that has a strategic role. The curriculum cannot stand and run alone but must plan, implemented, controlled, and evaluated. The importance of curriculum management is that curriculum management includes planning, implementing, and evaluating curriculum activities to produce quality output. Under the educational goals, curriculum management dramatically affects the success of schools' learning process. If the curriculum management does not go well, the school's teaching and learning process will experience obstacles so that the goals to be achieved through the teaching and learning process are also constrained (Bailey et al., 2002; Machin, 2014). On the other hand, if curriculum management is organizing well, the school's conditions will be conducive to developing a quality learning process (Suryana, 2019; Viciana \& Mayorga-Vega, 2016). In general, in Indonesia, curriculum management must be developed according to the 2013 Curriculum (Kurniasih \& Sani, 2014; Winangun, 2020). Therefore, the autonomy given to schools in managing the curriculum does not only prioritize the needs and achievement of school targets but also carry out national policies (Lazwardi, 2017; Purwadhi, 2019). For this reason, in order to achieve educational goals, structured planning is needed. Teaching and learning can be made more meaningful by understanding the aims of education. It should then understand as the basis of an educational taxonomy, in which appropriate teaching and learning practices can identify the domain of educational objectives (Kurangi et al., 2017; Varfolomeyev et al., 2015). 


\section{Conclusion}

Based on the description above, the curriculum is essential in the success of the learning process. Under the curriculum's success, good management following the plan, organize, implement, and evaluate stages. Curriculum management is critical, especially when a school integrates two curricula to run simultaneously. The integration of two curricula is possible because they have the same characteristics and the ability to manage them and socialize them with all parties. To support the running of curriculum management properly, of course, requires evaluation. Evaluation is needed to ensure that the planned curriculum achieves the stated goals and gives the expected results with the birth of a young generation who are superior, critical, and able to compete in the international world.

\section{References}

Aulia, S. (2020). Pola Perilaku Konsumen Digital Dalam Memanfaatkan Aplikasi Dompet Digital. Jurnal Komunikasi, $12(2)$,

$311-324$ http://journal.untar.ac.id/index.php/komunikasi/article/view/9829.

Aziz Hussin, A. (2018). Education 4.0 Made Simple: Ideas For Teaching. International Journal of Education and Literacy Studies, 6(3), 92. https://doi.org/10.7575/aiac.ijels.v.6n.3p.92.

Bahtiar, R. S. (2019). Persepsi Pelaksanaan Kurikulum 2013 Sekolah Dasar. Pendas: Jurnal Ilmiah Pendidikan Dasar, 4(2), 174-184. http://www.journal.unpas.ac.id/index.php/pendas/article/view/1752.

Bailey, M., Floersheim, R. B., \& Ressler, S. J. (2002). Course assessment plan: A tool for integrated curriculum management. Journal of Engineering Education, 91(4), 425-434. https://doi.org/10.1002/j.2168-9830.2002.tb00728.x.

Budiani, S., Sudarmin, \& Syamwil, R. (2017). Evaluasi Implementasi Kurikulum 2013 di Sekolah Pelaksana Mandiri. Innovative Journal of Curriculum and Educational Technology, 6(1), 45-57. https://journal.unnes.ac.id/sju/index.php/ujet/article/view/15998.

Fernandes, R. (2019). Relevansi Kurikulum 2013 dengan kebutuhan Peserta didik di Era Revolusi 4.0. Jurnal Socius: Journal of Sociology Research and Education, 6(2), 70-80. http://socius.ppj.unp.ac.id/index.php/socius/article/view/157.

Haryanti, Y. D., Sapriya, \& Pambudhi, T. (2021). Pengembangan Model Penilaian Autentik Pada Kurikulum 2013 Di Sekolah Dasar. Jurnal Cakrawala Pendas, 7(1), 27-39.

Idhamani, A. P. (2020). Dampak Teknologi Informasi terhadap Minat Baca Siswa. UNILIB: Jurnal Perpustakaan, 11(1), 35-41. https://doi.org/10.20885/unilib.vol11.iss1.art4.

Kurangi, B. K., Nanjwade, B. K., \& Jangade, N. M. (2017). Education Methodology: Curriculum Management. World Journal of Pharmacy and Pharmaceutical Sciences, 6(2), 1385-1396.

Kurniasih, I., \& Sani, B. (2014). Sukses Mengimplementasikan Kurikulum 2013 (1st ed.). Kata Pena.

Lazwardi, D. (2017). Manajemen kurikulum sebagai pengembangan tujuan pendidikan. Al-Idarah: Jurnal $\begin{array}{lll}\text { Kependidikan Islam, } & 7(1), & 119-125 .\end{array}$ http://ejournal.radenintan.ac.id/index.php/idaroh/article/view/1112.

Machin, A. (2014). Implementasi Pendekatan Saintifik, Penanaman Karakter dan Konservasi pada Pembelajaran Materi Pertumbuhan. Jurnal Pendidikan IPA, 3(1), 28-35.

Maudina, A. N., \& Hasanah. (2020). Implementasi Integrasi Kurikulum 2013 Dan Kurikulum Cambridge Di $\begin{array}{lllll}\text { SMP Al-Syukro Ciputat. Jurnal } & \text { Qiro'ah, 10(1), 18. }\end{array}$ https://ejurnal.iiq.ac.id/index.php/qiroah/article/view/159.

Pangondian, R. A., Insap Santosa, P., \& Nugroho, E. (2019). Faktor - Faktor Yang Mempengaruhi Kesuksesan Pembelajaran Daring Dalam Revolusi Industri 4.0. Sainteks 2019, 1(1), 56-60.

Purwadhi. (2019). Curriculum Management in the 21st Century Learning. Jurnal Pendidikan Sains Sosial Dan Kemanusiaan, 12(2), 143-156. http://www.journals.mindamas.com/index.php/sosiohumanika/article/view/1238.

Rahmadoni, J. (2018). Isu Global Manajemen Pembiayaan Pendidikan Di SD Indonesian Creative School Pekanbaru. Jurnal Manajemen, Kepemimpinan, Dan Supervisi Pendidikan, 3(2), 161-169. https://jurnal.univpgri-palembang.ac.id/index.php/JMKSP/article/view/1855.

Safitri, D., \& Oktaviana, M. (2017). Implementasi Penilaian Autentik Kurikulum 2013 (Studi Kasus Guru IPS di SMP Labschool Jakarta). Edukasi IPS, 1(1), 31-40. http://journal.unj.ac.id/unj/index.php/eips/article/view/3207.

Sugiyono. (2015). Metode Penelitian Pendidikan pendekatan Kuantitatif, Kualitatif dan R\&D. Alfabeta, Bandung.

Suryana, Y. (2019). Manajemen Kurikulum Dalam Meningkatkan Mutu Lulusan. Jurnal Islamic Education 
Manajemen, 4(2), 257-266. http://journal.uinsgd.ac.id/index.php/isema/article/view/6026.

Varfolomeyev, A., Pitukhin, E., \& Nasadkin, M. (2015). Curriculum management information system. 8th International Conference of Education, Research and Innovation.

Verawadina, U., Jalinus, N., \& Asnur, L. (2019). Kurikulum Pendidikan Vokasi Pada Era Revolusi Industri 4.0. Jurnal Pendidikan, 20(1), 82-90. http://www.jurnal.ut.ac.id/index.php/JP/article/view/240.

Viciana, J., \& Mayorga-Vega, D. (2016). Innovative teaching units applied to Physical Education-changing the curriculum management for authentic outcomes. Kinesiology, 48(1), 142-152. https://hrcak.srce.hr/index.php?id_clanak_jezik=237137\&show=clanak.

Winangun, I. M. A. (2020). Media Berbasis Budaya Lokal dalam Pembelajaran IPA SD. Edukasi: Jurnal Pendidikan Dasar, 1(1), 65-72.

Yamin, M. R., \& Karmila. (2019). Analisis Kebutuhan Pengembangan Media Pembelajaran Berbasis Cartoon dalam Pembelajaran IPA pada Materi Lingkungan Kelas III SD. Biology Teaching and Learning, 2(2), 159-170. 